\title{
COVID-19 utáni nem adekvát sinustachycardia, terhelési intolerancia kezelése ivabradinnal
}

\author{
Tomcsányi János
}

\author{
Budai Irgalmasrendi Kórház, Kardiológia, Budapest \\ Levelezési cím: \\ Dr. Tomcsányi János, 1023 Budapest, Árpád fejedelem u.7. \\ E-mail: tomcsányij@gmail.com
}

36 éves férfi poszt-COVID-19 kezdődő inadekvát sinustachycardia ivabradinnal történő kezelése kerül bemutatásra. A szerző ismerteti a poszt-COVID-19-es csökkent terhelhetőség ezen szövődményét, illetve a lehetséges kezeléseket. Kulcsszavak: COVID-19, tacyhcardia, ivabradin

Ivabradine for inappropriate sinustachycardia after COVID-19 infection

Treatment of inadequate sinus tachycardia starting with COVID-19 in 36-year-old men with ivabradine is presented. The author describes this complication of post-COVID-19 palpitations. exercise intolerance and the possible treatments.

Keywords: COVID-19 infection, tachycardia, ivabradine

Az inadekvát sinustachycardia (IAST) legföbb jellemzői a magas nyugalmi frekvencia $(>100 / \mathrm{min}, 24$ órás $>90 / \mathrm{min}$ ), illetve a terhelésre jelentkező túlzott frekvencianövekedés (1), amit nem hyperthyreosis, hypoxia, szívelégtelenség, anémia okoz. Jelenleg egy újabb ok jelentkezett, ami IAST-hez hasonló tüneteket okoz, ami palpitáció, gyengeség és legfőképpen terhelési intolerancia formájában nyilvánul meg. Ez az új ok a COVID-19-fertőzés. Ez adja a jelen esetismertetés aktualitását.

\section{Esetismertetés}

36 éves általános iskolai tanár anamnézisében több mint két hónappal ezelőtt lezajlott COVID-19-fertőzés szerepel. Két napig magas láza volt, nagyon intenzív fájdalmas torokgyulladással, rhinitissel. Izérzészavara nem volt, szaglászavara is csak két napig tartott. A tanárembert a hosszan fennálló terhelési intolerancia, palpitáció miatt vizsgáltuk. Laborvizsgálata negatív volt, beleértve a hsTroponin T-t (4 ng/l) és a pajzsmirigyfunkciót (TSH 1,8 mlU/l, fT4: 20,37 pmol/l, fT3: 6,47 pmol/l). Szívultra- hang-vizsgálat strukturális szívbetegséget nem igazolt. Az elektrokardiogram 100/min körüli nyugalmi sinusritmust mutatott inkomplett jobb Tawara-szár-blokkal (1. ábra). A Holter-vizsgálat során az átlagfrekvencia 90/ min átlagfrekvenciát mutatott, de terhelésre (iskolába sietés) inadekvátan magas 180/min frekvenciájú sinustachycardia lépett fel, dyspnoe kíséretében (2. ábra). A betegnél ezen panaszokat okozó sinustachycardiák miatt ivabradint kezdtünk $2 \times 5 \mathrm{mg}$ dózisban. A kontroll 3 hét múlva következett be, amikor is a beteg terheléses panaszai megszüntek. Nyugalmi szívfrekvenciája jelentősen csökkent (3. ábra), míg a kontroll Holteren az átlag sinusfrekvencia 79/min-re csökkent. A frekvenciahisztogramon a reggeli terhelés változatlanul megvolt, de kisebb mértékben (4. ábra) így az ivabradinkezelés további folytatása mellett döntöttünk.

\section{Megbeszélés}

A COVID-19-fertőzés után minden 10. betegnek perzisztálnak a tünetei. Ezen tünetek legföképpen a fáradékonyságban, dyspnoeban nyilvánulnak meg. A tüne- 

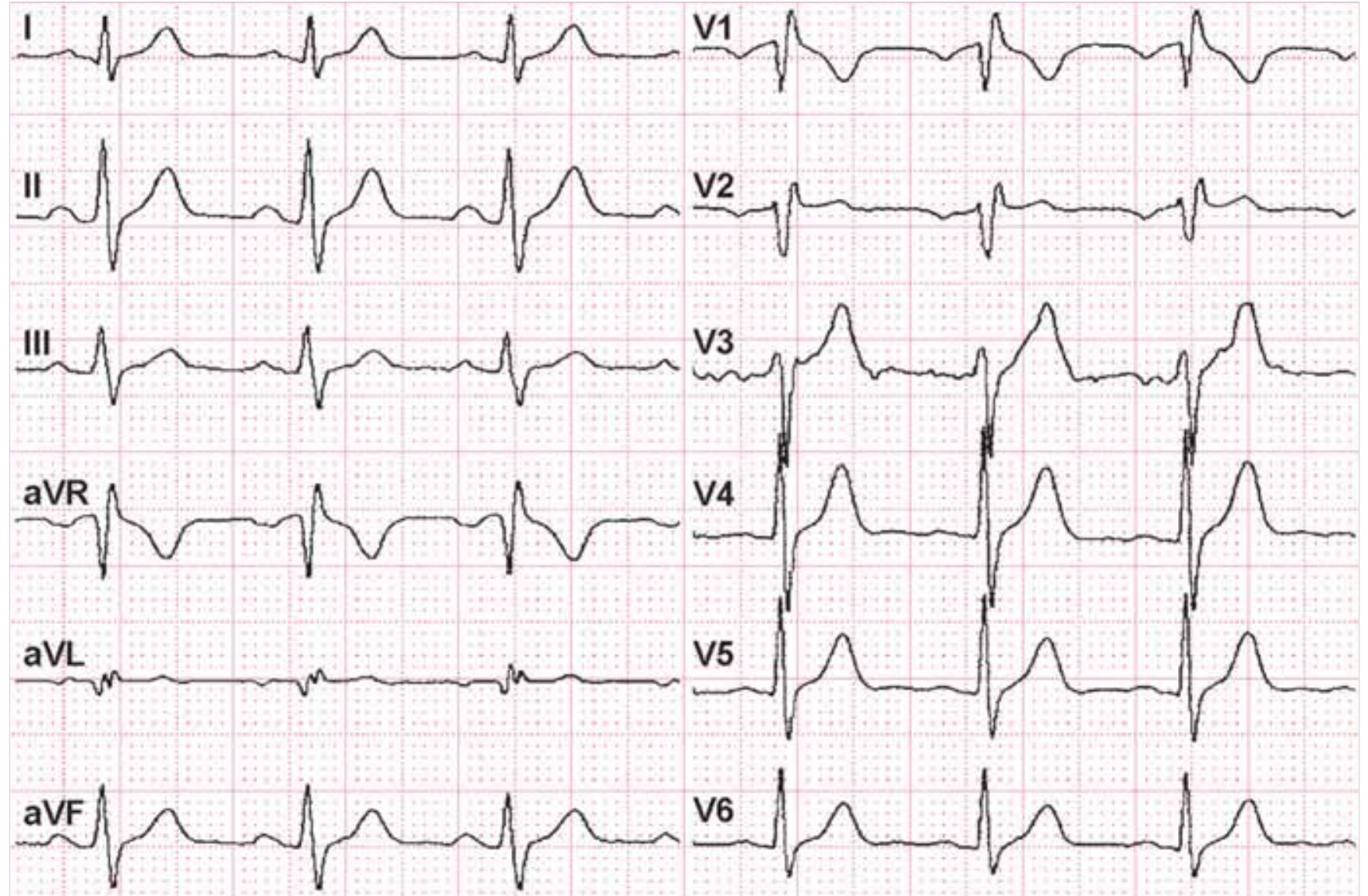

1. ÁBRA. Nyugalmi 12 elvezetéses EKG. Magas sinusfrekvencia, inkomplett JTSZB
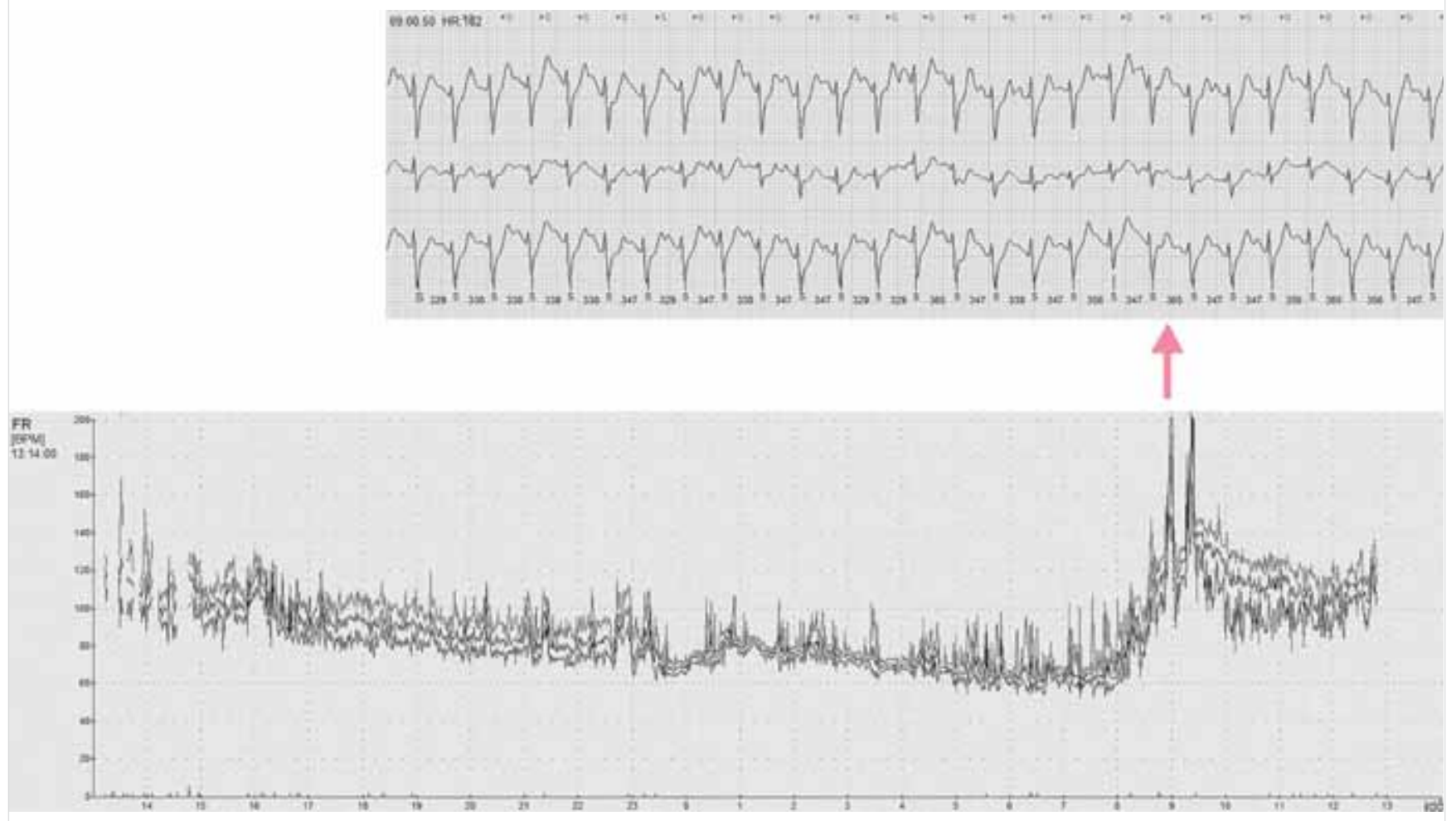

2. ÁBRA. Holter-frekvencia hisztogram. A reggeli munkába sietéskor magas frekvenciájú sinustachycardia 

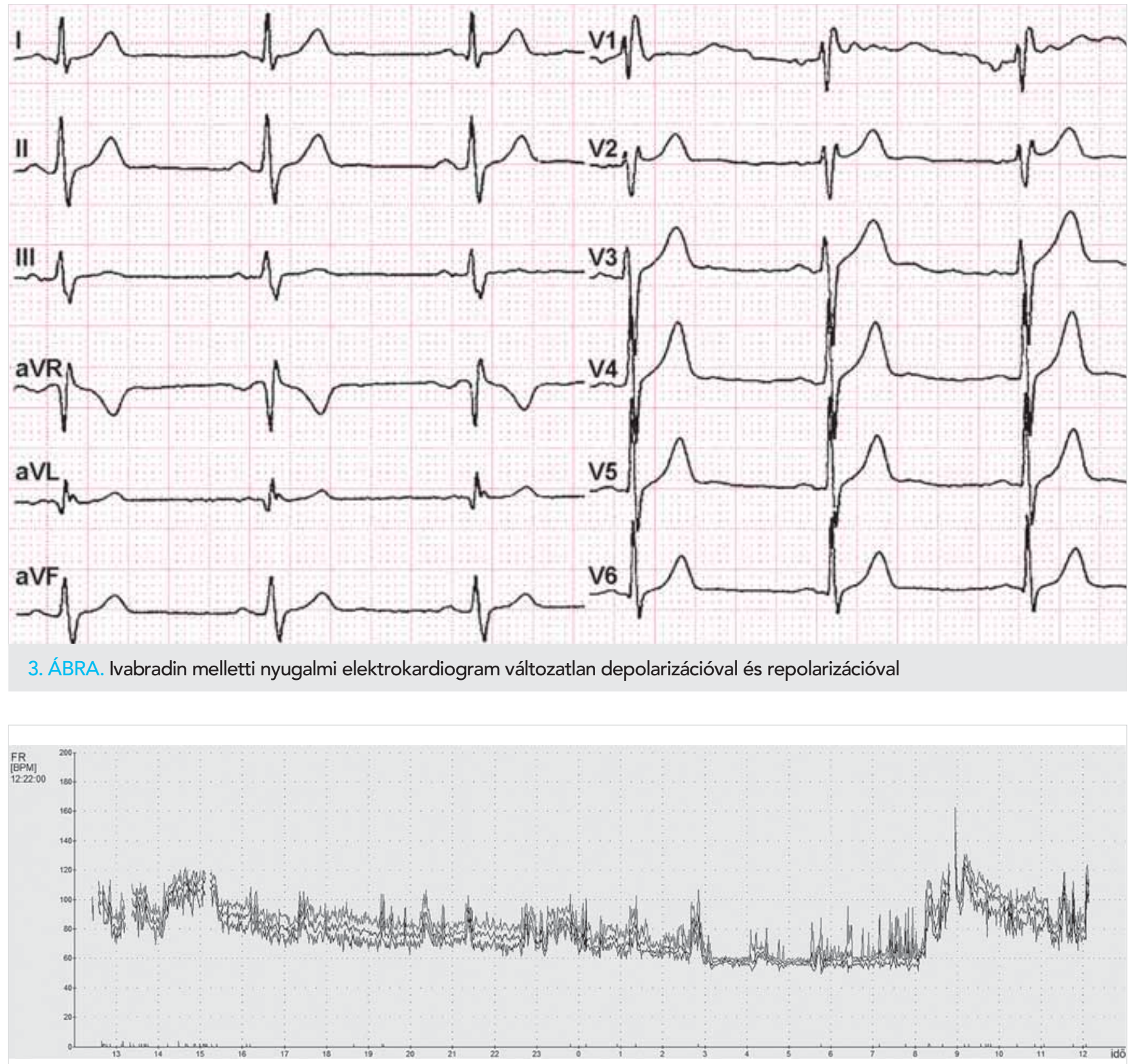

4. ÁBRA. Holter-frekvencia hisztogramja napi $10 \mathrm{mg}$ ivabradin mellett. A reggeli munkába sietéskor alacsonyabb frekvenciakiugrás látható

tek hosszú ideig perzisztálhatnak a COVID-19-fertőzés után is (2). Az esetek egy részében a panaszokat, terhelési intoleranciát, a magas pulzusszámot, illetve inadekvát sinustachycardiát a posztinfekciós autonóm diszfunkció okozza $(3,4)$. Ennek az autonóm diszfunkciónak számtalan klinikai megnyilvánulási formája lehet, mint a syncopét okozó ortosztatikus hipotónia (5), illetve posturalis tachycardia-szindróma. Esetünk érdekessége, hogy az akut fázisban a neurológiai tünetek csak igen enyhék voltak, átmenetiek. Ugyanakkor a beteg panaszait okozó tünetek csak az akut fertőzés után manifesztálódtak és hosszan fennálltak. Korábban hasonló tünete, illetve panasza nem volt.
Ezen tüneteknek oki kezelése nincsen, tüneti kezelése pedig vagy a béta-blokkoló vagy a sinuscsomóra direktben ható ivabradin mint az IAST esetében (6, 7). Mindkét szer alkalmazása off-label (indikáción túli gyógyszeralkalmazás), de nem is lehet más, hiszen egy eddig ismeretlen pandémia okozta tünetek kezelése szinte minden esetben off-label.

Az ivabradinnak az inaproppriate sinustachycardiára való kedvező hatása esetismertetésekből régóta ismert (7). Egy kisebb randomizált vizsgálat volt, ami azt mutatta, hogy a betegeknél a nyugalmi frekvenciát 12/ min-nel, a 24 órás átlagfrekvenciát 11/min-nel és a terhelésre jelentkező sinustachycardiát 18/min-nel csök- 
kentette. Ezen értékek mellett a betegek tüneteit több mint $70 \%$-ban megszüntette (8). A metoprolol és ivabradin összehasonlítása azt mutatta, hogy hasonló hatásosság mellett gyakoribb mellékhatások (hipotónia, bradycardia) miatt a metoprolol dózisát többször kellett csökkenteni, kevésbé csökkentette a beteg szimptomatikáját, mint az ivabradin (9).

Egy újabb metaanalízis szerint a radiofrekvenciás abláció csak terápiarefrakter esetekben alkalmazható mert viszonylag magas a szövődményráta és gyakori a tünetek rekurrenciája (10).

A béta-blokkoló carvedilol és ivabradin összehasonlítására poszt-COVID-19-es tachycardiában csak kis betegszámú vizsgálat áll a rendelkezésünkre, ami azt igazolta, hogy mindkét szer hatékony, de a betegeknél az ivabradin jobban csökkentette a tüneteket (11). Napjainkban megjelent kisszámú randomizált vizsgálat szintén az ivabradin effektivitását, biztonságosságát és az életminőségre kifejtett kedvező hatását eredményezte (12).

Mindezek alapján érthető, hogy miért az ivabradint választottuk a tünetes sinustachycardia kezelésére, ami jelen esetben a korábbi vizsgálatokhoz hasonlóan a napi frekvenciaátlagban egy 10/min frekvenciacsökkenést eredményezett, de ami még ennél is fontosabb, hogy a terhelésre megszünt a 180 feletti sinustachycardia és az ezzel járó tünetek. Napi $2 \times 5$ mg ivabradin mellett 25/min-nel csökkent a terhelési frekvencia (habár nincs a terhelés standardizálva). A dózist tovább lehetett volna emelni $2 \times 7,5$ mg-ra, de a betegnek megszüntek a panaszai a $2 \times 5 \mathrm{mg}$ mellett is, ezért nem lett tovább emelve a dózis. Egy hónappal később felajánlottuk a dózis csökkentését, illetve elhagyását, de a páciens annyira jól érezte magát ezen kezelés mellett, hogy kérte a kezelés további folytatását.

\section{Nyilatkozat}

A szerző kijelenti, hogy az esetismertetés megírásával kapcsolatban nem áll fenn velük szemben pénzügyi vagy egyéb lényeges összeütközés, ösz- szeférhetetlenségi ok, amely befolyásolhatja a közleményben bemutatott eredményeket, az abból levont következtetéseket vagy azok értelmezését.

Irodalom

1. Olshansky B, Sullivan RM. Inappropriate sinus tachycardia. J Am Coll Cardiol 2013; 61: 793-801.

https://doi.org/10.1016/j.jacc.2012.07.074

2. Canfi $A$, Bernabel $R$, Landl $F$, et al. Persistent symptoms in patients after acute COVID-19. JAMA 2020; 324: 603-5.

https://doi.org/10.1001/jama.2020.12603

3. Dani M, Dirksen A, Taraborrelli P, et al. Autonomic dysfunction in „long COVID": rationale physiology and management strategies. Clin Med 2021; 21: e3-7. https://doi.org/10.7861/clinmed.2020-0896 4. Goldstein DS. The extended autonomic system, dyshomeostasis and COVID-19. Clin Auton Res 2020; 30: 299-315.

https://doi.org/10.1007/s10286-020-00714-0

5. Arabadzisz H, Tako K, Tomcsányi J. Syncope mint a SARS-COV2-fertőzés egyedüli tünete. Orv Hetil 2021; 162(7): 243-245.

https://doi.org/10.1556/650.2021.32088

6. Koruth JS, Lala A, Pinney S, et al. The clinical use of ivabradine. J Am Coll Cardiol 2017; 70: 1777-84.

https://doi.org/10.1016/j.jacc.2017.08.038

7. Caló L, Rebecchi M, Sette A, et al. Efficacy of ivabradine administration inappropriate sinus tachycardia. Heart Rhythm 2010; 7 : 1318-23. https://doi.org/10.1016/j.hrthm.2010.05.034

8. Cappato R, Castevecchio S, Ricci C, et al. Clinical efficacy of ivabradine in patients with inappropriate sinus tachycardia: a prospective randomized, placebo-controlled, double-blind, crossover evaluation. J Am Coll Cardiol 2012; 60: 1323-1329.

https://doi.org/10.1016/j.jacc.2012.06.031

9. Ptaszynski P, Kaszmanek K, Ruta J, et al. Metoprolol succinate vs. ivabradine in the treatment of inappropriate sinus tachycardia in patients unrespnonsive to previous pharmacological therapy. Europace 2013; 15: 116-21. https://doi.org/10.1093/europace/eus204 10. Rodriquez-Manero M, Kriedieh B, AL Rifai M, et al. Ablation of inappropriate sinus tachycardia. J Am Coll Cardiol Clin Electrophysiol 2017; 3: 253-65. https://doi.org/10.1016/j.jacep.2016.09.014

11. Jadhazy K, Jariwola P. Ivabradin versus carvedilol in the management of post-covid 19 palpitations with sinus tachycardia. Indian Heart J 2020; 72: S33.

12. Taub PR, Zadonrian A, Lo HC, et al. Randomized trial of ivabradine in patients with hyperadrenergic postural orthostatic tachycardia syndrome. J Am Coll Cardiol 2021; 77(7): 861-871.

https://doi.org/10.1016/j.jacc.2020.12.029 